\title{
Éditorial
}

\section{De la nécessité d’une réflexion épistémologique en STAPS}

La principale motivation de ce numéro spécial est née du constat de la faiblesse de la formation épistémologique des doctorants et donc des futurs enseignants-chercheurs. Les enseignements dédiés des formations doctorales, lorsqu'ils sont présents, se limitent généralement à une histoire des sciences, essentiellement descriptive. Trop souvent les doctorants sont imprégnés de l'épistémologie de leur discipline de référence, à laquelle ils accordent une légitimité absolue.

Mais les STAPS sont par nature multidisciplinaires, générant a minima la cohabitation d'épistémologies contrastées, au pire des conflits frontaux à l'occasion des procédures de qualification, de recrutement, de répartition des moyens. Nous pensons que le développement harmonieux de notre section doit s'appuyer sur une connaissance intime de l'autre et de ses différences.

D'un autre côté les STAPS sont un lieu où des approches interdisciplinaires peuvent naturellement émerger, autour d'objets communs. Un certain nombre de laboratoires, soit par intérêt propre, soit sous pression politique, s'orientent vers cette voie. Mais au-delà des évidences, cette posture interdisciplinaire suscite d'importantes questions épistémologiques.

Enfin les STAPS, de part leur histoire et l'objet qui les fédère sont aussi un lieu de production de savoirs techniques. Cette spécificité entraîne d'autres oppositions, entre épistémologies scientifiques et conceptions plus pragmatiques. Il y a là aussi une forte querelle en légitimité, sur laquelle tend en plus à se greffer des revendications statutaires.

Ce numéro spécial regroupe un ensemble de contributions qui témoignent de la complexité des problématiques épistémologiques qui traversent la $74^{\mathrm{e}}$ section. Les trois premiers articles proposent des analyses fouillées des cohabitations disciplinaires et des frictions qui en résultent. Loïc Jarnet revient sur le problème fondamental de l'épistémologie des STAPS, en tant que discipline universitaire. On connaît la controverse fameuse qui a opposé Georges Vigarello et Pierre Parlebas lors de la création de la $74^{\mathrm{e}}$ section. L'auteur approfondit cette thématique par une analyse critique des différentes lectures de la cohérence des STAPS qui ont été proposées ces dernières décennies. Il conclut en présentant les contours d'une épistémologie réaliste suggérant que les STAPS puissent être une science à part entière. Matthieu Delalandre se livre à une analyse des controverses en sciences du sport. Il montre comment ces controverses débordent souvent de la rationalité scientifique, notamment au niveau de tensions entre une conception académique et une conception plus pragmatique de la production des savoirs. Yannick Vanpoulle développe une réflexion sur les modes de connaissance, leurs caractéristiques et leurs limites. Il évoque des perspectives de développement et d'évolution paradigmatique des démarches structurant actuellement la recherche en STAPS.

Les deux articles suivants se penchent sur l'interdisciplinarité. Souvent jugée naturelle dans une section universitaire regroupant des scientifiques issus de disciplines diverses, encouragée par les politiques de recherche, l'interdisciplinarité n'émerge cependant qu'au prix de multiples difficultés. Cécile Collinet, Philippe Terral et Patrick Trabal montrent que l'interdisciplinarité s'opérationnalise de manière très différente d'un laboratoire à l'autre. Patrick Fargier, Jean Camy, Claire Perrin et Alain Belli analyse la manière dont des centres de recherche européens tentent de faire fonctionner cette démarche interdisciplinaire.

Les deux articles suivants analysent les processus de migration des concepts entre disciplines. Léa Gottsmann et Didier Delignières rendent compte de la difficile émergence du concept de compétence dans le discours théorique de l'Éducation Physique. Utilisant le cadre bachelardien des obstacles épistémologiques, ils montrent comment un concept peut être happé par le sens commun. Mathieu Quidu analyse l'incorporation récente par les STAPS du concept de fractales. Au-delà de la description du développement progressif d'un programme de recherche, il pose le problème de l'innovation théorique, et de son évolution vers l'état de science normale.

Enfin Patrice Van den Reysen propose une présentation fouillée de la pensée épistémologique de Karl Popper. On retient souvent de cet auteur quelques formules fameuses, liées à la nécessaire réfutabilité du savoir scientifique. Cet article tente de présenter de manière beaucoup plus approfondie l'épistémologie poppérienne.

Didier Delignières Université de Montpellier 


\section{Editorial}

\section{About the need for an epistemological reflection in sport sciences}

The proposal of this special issue originated in the awereness of the weakness of epistemological training of $\mathrm{PhD}$ students and thus of the future academic researchers. Specific courses in doctoral programs, when present, are generally limited to an essentially descriptive history of sciences. Often $\mathrm{PhD}$ students are imbued with the epistemology of their reference discipline, to which they give absolute legitimacy.

However, sport sciences are multidisciplinary in nature, inducing at minimum a cohabitation between contrasted epistemologies and at worst some frontal conflicts during qualification procedures, recruitment, and distribution of resources. We believe that the harmonious development of sport sciences in the university must be based on an intimate knowledge of each other and its differences.

On the other hand, sport sciences are a place where interdisciplinary approaches may naturally emerge around common objects. A number of laboratories, either by self-interest, or under political pressure, are moving towards that direction. But beyond the obvious, this interdisciplinary posture raises important epistemological questions.

Finally sport sciences, because of their history and the purpose that unites them, are also a place for production of technical knowledge. This characteristic leads to other oppositions between scientific epistemology and more pragmatic designs. This represents another potential conflict of legitimacy, closely related to statutory claims.

This special issue is a collection of contributions that reflect the complexity of the epistemological issues that run through sport sciences. The first three articles offer detailed analyzes of disciplinary cohabitations and frictions that result. Loïc Jarnet returns to the fundamental problem of the epistemology of sport sciences, as an academic discipline. A famous controversy has pitted Georges Vigarello and Pierre Parlebas during the creation of sport sciences in the university. The author deepens this theme by a critical analysis of different readings of the consistency of sport sciences, that have been proposed in recent decades. He concludes by presenting the outlines of a realistic epistemology suggesting that sport sciences could be a science in itself. Matthieu Delalandre offers an analysis of controversies in sports sciences. He shows how these controversies often overflow out of scientific rationality, particularly in terms of tensions between academic points of view and more pragmatic conceptions of knowledge production. Yannick Vanpoulle develops a reflection about the modes of knowledge, their characteristics and limitations. It evokes the perspectives of development and the evolution of the paradigmatic approaches that currently structure research in sport sciences.

The next two articles focus on interdisciplinarity. Often considered natural in a university section involving scientists from various disciplines, encouraged by research politics, interdisciplinarity emerges at the price of multiple difficulties. Cécile Collinet, Philippe Terral and Patrick Trabal show that interdisciplinarity is operationalized in very different ways from one laboratory to another. Patrick Fargier, Jean Camy, Claire Perrin et Alain Belli analyzes how European research centers try to develop this interdisciplinary approach.

The following two papers analyze the process of migration of concepts between disciplines. Léa Gottsmann and Didier Delignières describe the difficult emergence of the concept of competence in the theoretical discourse of Physical Education. Using the Bachelardian framework of epistemological obstacles, they show how a concept can be snapped up by common sense. Mathieu Quidu analyzes the recent incorporation of the concept of fractals in sport sciences. Beyond the description of the gradual development of a research program, this paper raises the problem of theoretical innovation, and its evolution toward normal science.

Finally, Patrice Van den Reysen offers a detailed presentation of the epistemological thought of Karl Popper. Often one retains from this author some famous principles related to the necessary falsifiability of scientific knowledge. This article attempts to present in much more details the Popperian epistemology.

Didier Delignières Université de Montpellier 